\title{
PRIORITAS PENGEMBANGAN OBJEK WISATA DI KOTA PADANG, PROVINSI SUMATERA BARAT
}

\author{
Tourism Development Priorities in Padang, West Sumatra
}

\section{Iswandi Umar ${ }^{1}$}

Diterima: 3 November 2017

Disetujui: 31 Juli 2018

\begin{abstract}
Abstrak. Indonesia merupakan salah negara yang memiliki potensi pengembangan objek wisata pantai. Jumlah kunjungan baik wisata domestik maupun mancanegara mengalami peningkatan setiap tahunnya. Penelitian ini bertujuan untuk menentukan prioritas pengembangan objek wisata pantai di Kota Padang. Prioritas pengembangan objek wisata ditentukan berdasarkan kesesuaian lahan dan indeks potensi pengembangan objek wisata. Kesesuaian lahan untuk kawasan objek wisata pantai mengunakan delapan indikator, yaitu: kecerahan perairan, tipe pantai, kedalaman pantai, substrat, kecepatan arus, tutupan karang hidup, rawan bencana, dan aksesbilitas. Indeks potensi pengembangan objek wisata pantai menggunakan lima kriteria, yaitu: penerimaan masyarakat, sarana dan prasarana penunjang, aktraksi budaya, dungan industri, dan dukungan pemerintah. Hasil penelitian menunjukkan objek wisata pantai Muaro Lasak merupakan kawasan prioritas utama pengembangan objek wisata pantai di Kota Padang, sedangkan objek wisata pantai Muaro Anai merupakan sebagai prioritas paling rendah.
\end{abstract}

Kata kunci : kesesuaian lahan, objek wisata, potensi, pengembangan, prioritas.

\begin{abstract}
Indonesia is one country that has the potential for development of tourist beach. Number of visits to both domestic and foreign travel has increased every year. This study aims to determine the priority of tourism development in the coastal city of Padang. Priority tourism development is determined by the suitability of land and tourism development potential index. Suitability of land for tourist beach area using eight indicators, namely: water transparency, type of beach, shore depth, substrate, current speed, live coral cover, hazards, and accessibility. Index development potential attraction beach using five criteria: community acceptance, facilities and supporting infrastructure, cultural performances, industry support, and government support. The results showed attraction Muaro peevish beach is the main priority areas of tourism development in the coastal city of Padang, while the beach a tourist attraction Muaro Anai is the lowest priority.
\end{abstract}

Keywords : development, priority, potential, land suitability, tourist attractions.

\section{PENDAHULUAN}

Pariwisata dapat didefinisikan sebagai serangkaian kegiatan yang bertujuan untuk bersantai, bisnis, agama dan kesehatan dalam waktu yang singkat pada suatu wilayah (Masron et al. 2015). Pengembangan wisata merupakan strategi penting sebagai upaya

\footnotetext{
${ }^{1}$ Jurusan Geografi Fakultas Ilmu Sosial, Universitas Negeri Padang, Kota Padang 25474
} 
untuk meningkatkan pembangunan ekonomi suatu wilayah. Dengan berkembangnya pariwisata, maka akan berdampak pada kemajuan industri pariwisata serta meningkatkan kesempatan kerja (Zhang 2013). Masron et al. 2015 menyatakan perkembangan industri pariwisata akan dapat menyerap sebesar 3-5 persen tenaga kerja pada suatu negara.

Hawkes et al. (1998) menyatakan keindahan dan keanekaragaman alam memiliki daya tarik yang tinggi untuk meningkatkan kunjungan wisata pada suatu wilayah. Menurut Salehudin et al. (2013) dalam Masron et al. (2015) sebagian besar wisatawan lebih tertarik pada objek wisata bahari. Indonesia merupakan negara yang memiliki $2 / 3$ wilayah laut dan memiliki garis pantai sepanjang $99093 \mathrm{~km}$. Sehingga memiliki potensi besar untuk penembangan industri pariwisata.

Data stratistik kunjungan wisatawan ke Indonesia periode 2010-2016 mengalami peningkatan rata-rata sekitar 7 persen/tahun. Pada tahun 2010 jumlah kunjungan wisatawan ke Indonesia sebanyak 493799 orang, dan tahun 2016 meningkat menjadi 740 450 orang. Peningkatan kedatangan wisata asing ke Indonesia berkontribusi besar terhadap pendapatan negara sebesar 3563 juta US\$ (BPS 2016).

Kota Padang memiliki beberapa objek wisata bahari yang sangat potensial untuk dikembangkan. Berdasarkan statistik pariwisata periode 2006-2016 terjadi peningkatan kunjungan wisata domestik dan mancanegara ke Kota Padang sebesar 2,6 persen pe tahun. Dengan peningkatan kunjungan pariwisata maka terjadi peningkatan daya serap tenaga kerja sebesar 1,4 persen per tahun. Berdasarkan latar belakang diatas maka penetian ini bertujuan untuk menentukan prioritas pengemangan objek wisata di Kota Padang, Provinsi Sumatera Barat.

\section{METODE PENELITIAN}

Lokasi penelitian ialah Kota Padang, Provinsi Sumatera Barat. Secara geografis, wilayah penelitian terdapat pada bajur $100^{\circ} 05^{\prime} 05^{\prime}-100^{\circ} 34^{\prime} 09^{\prime \prime}$ BT dan lintang $00^{\circ} 44^{\prime} 00^{\prime \prime}$ $01^{\circ} 08^{\prime} 35^{\prime \prime}$ LS. Wilayah penelitian memiliki luas 69.496 ha. Lokasi penelitian dapat dilihat pada Gambar 1. Penelitian ini dilakukan selama enam bulan, periode penelitian ini antara bulan Agustus 2016 sampai dengan bulan Januari 2017.

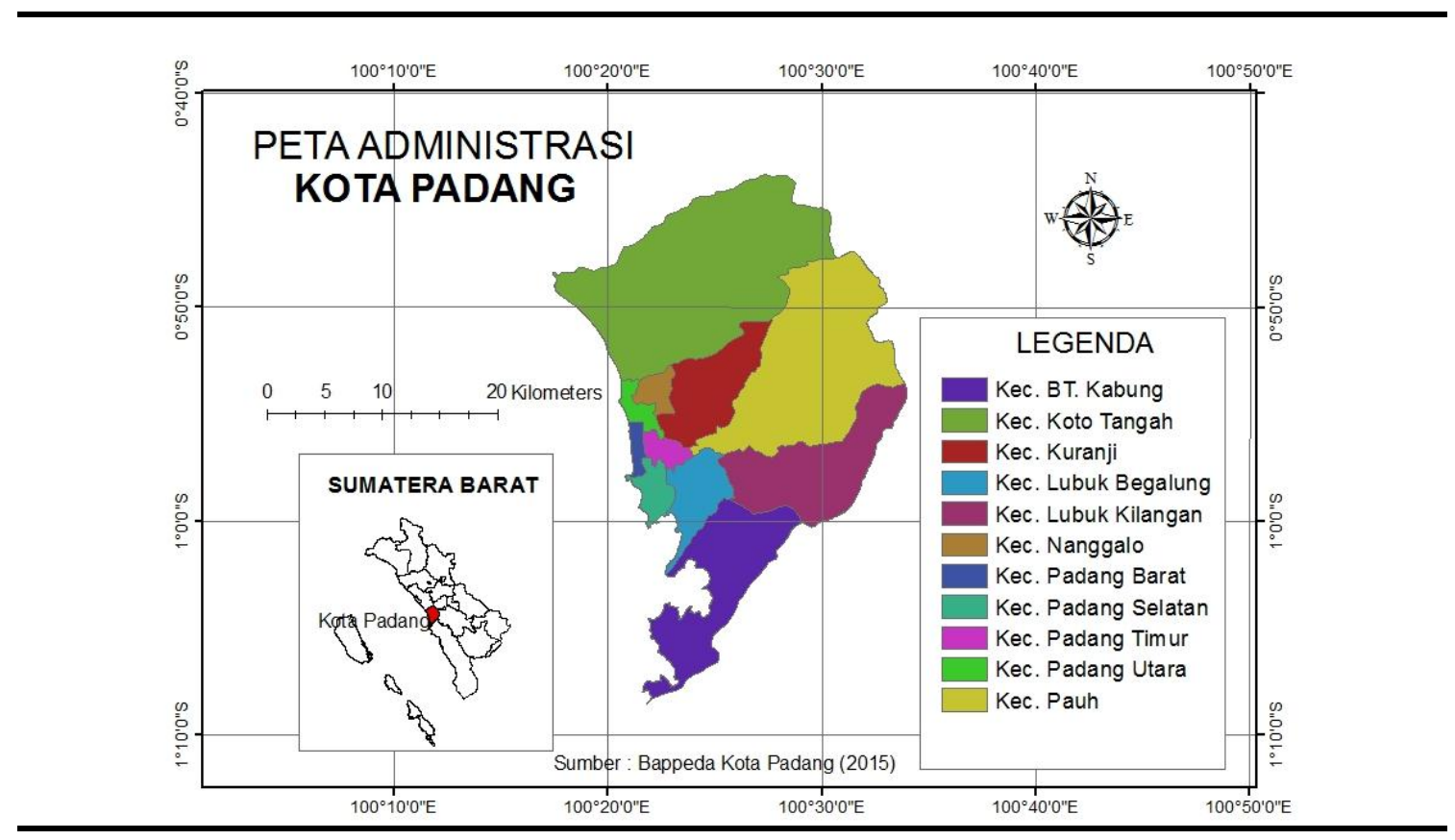

Gambar 1. Lokasi Penelitian 
Menurut Hardjowigeno dan Widiatmaka (2007) kelas kesesuaian lahan untuk objek wisata pantai dapat dibedakan atas empat kategori, yaitu: sangat sesuai (S1), sesuai (S2), sesuai marjinal (S3), dan tidak sesuai (N). Zona sangat sesuai (S1) merupakan kawasan yang sangat sesuai untuk kawasan objek wisata pantai dan tidak memiliki faktor pembatas. Zona sesuai (S2) merupakan lahan memiliki faktor pembatas cukup berat dan membutuhkan perbaikan untuk dapat dimanfaatkan untuk kawasan objek wisata pantai. Selanjutnya, zona sesuai marjinal (S3) merupakan lahan yang memiliki faktor pembatas sangat berat dan membutuhkan biaya yang mahal dalam perbaikan untuk dapat dimanfaatkan sebagai kawasan objek wisata pantai. Sedangkan zona tidak sesuai (N) merupakan lahan yang memiliki faktor pembatas sangat berat dan tidak dapat dilakukan perbaikan.

Kesesuaian lahan untuk kawasan pariwisata menggunakan kriteria yang digunakan USDA (1971), Hardjowigeno dan Widiatmaka (2007), Aklibasinda dan Bulut (2014) yaitu: kecerahan perairan, tipe pantai, kedalaman pantai, subtrat, kecepatan arus, tutupan karang hidup, rawan bencana, dan aksesbilitas. Masing-masing kriteria dibedakan menjadi sub kriteria. Skor ditentukan hasil perkalian antara bobot kriteria dengan harkat sub kriteria. Tabel 1 merupakan kriteria yang digunakan untuk penentuan kesesuaian lahan untuk kawasan pariwisata.

Tabel 1. Kriteria kesesuaian lahan untuk kawasan wisata pantai

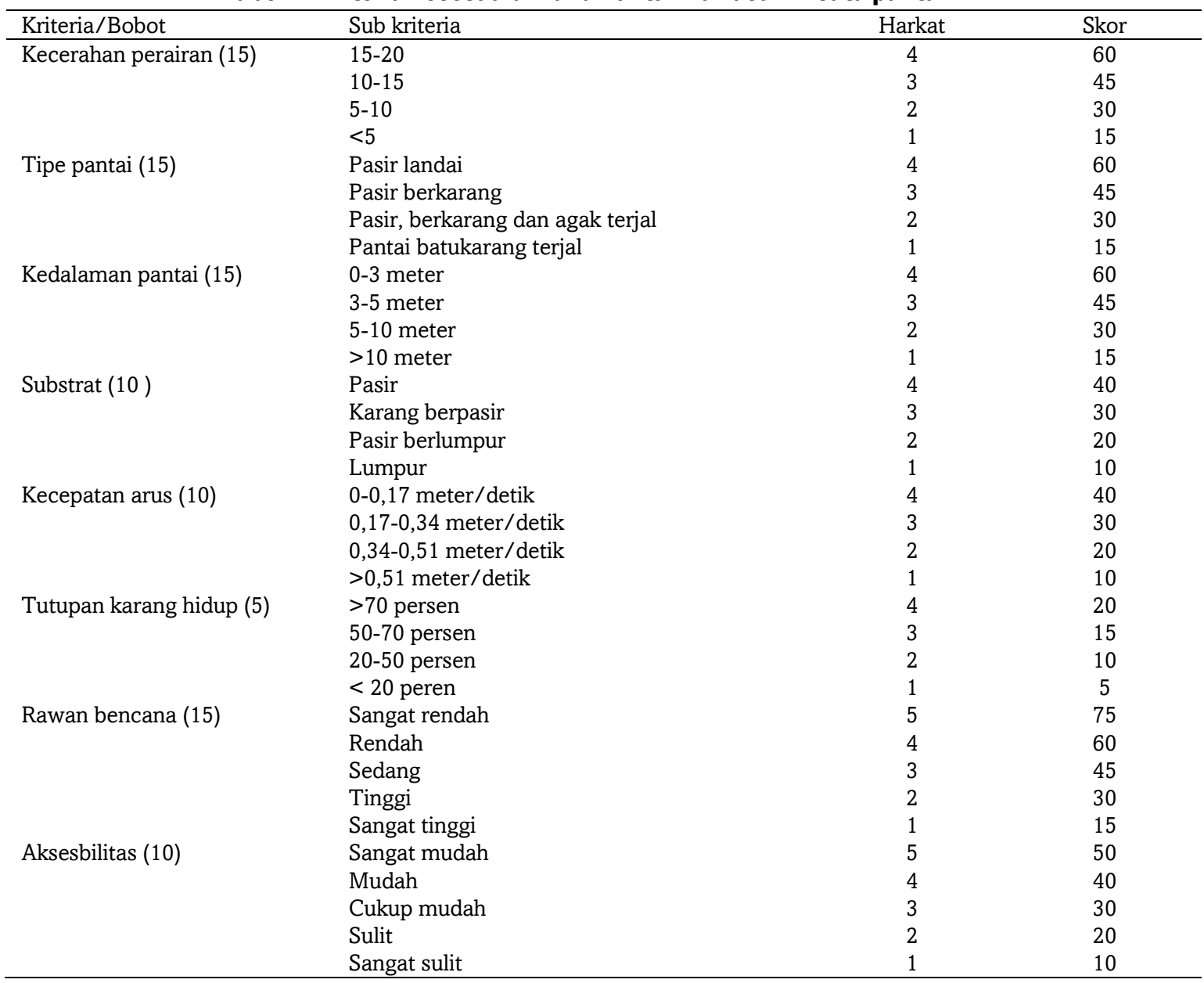

Sumber : USDA (1971), Hardjowigeno dan Widiatmaka (2007), Aklibasinda dan Bulut (2014). 
Untuk menentukan kelas interval zonasi kesesuaian lahan untuk kawasan wisata pantai digunakan persamaan 1 , yaitu:

$$
I=\left(\overline{\overline{1})} \frac{c-b}{k}\right.
$$
Keterangan
I = besar jarak interval kelas
$\mathrm{c}=$ jumlah skor tertinggi
$\mathrm{b}=$ jumlah skor terendah
$\mathrm{k}=$ jumlah kelas yang diinginkan

Berdasarkan Tabel 1, total skor tertinggi adalah 405, sedangkan total skor terendah yakni sebesar 95. Jumlah kelompok kelas yang akan ditentukan sebanyak empat kategori yakni sangat sesuai (S1), sesuai (S2), sesuai marjinal (S3), dan tidak sesuai (N). Maka diperoleh interval kelas sebesar 78. Tabel 2 disajikan kelas kesesuaian lahan untuk kawasan wisata pantai.

Tabel 2. Kelas kesesuaian untuk kawasan wisata pantai

\begin{tabular}{lcl}
\hline \multicolumn{1}{c}{ Kelas kesesuaian } & Kelas interval & $\begin{array}{c}\text { Indeks kesesuaian untuk kawasan } \\
\text { wisata pantai }\end{array}$ \\
\hline Sangat sesuai (S1) & $330-405$ & Zona wisata pantai sangat sesuai \\
Sesuai (S2) & $252-329$ & Zona wisata pantai sesuai \\
Sesuai marjinal (S3) & $173-251$ & Zona wisata pantai sesuai marjinal \\
Tidak sesuai (N) & $95-172$ & Zona wisata pantai tidak sesuai \\
\hline
\end{tabular}

Sumber: USDA (1971), Hardjowigeno dan Widiatmaka (2007), Aklibasinda dan Bulut (2014).

Selanjutnya untuk menentukan indeks penilaian potensi pengembangan ditentukan berdasarkan pendapat pakar dengan menggunakan metode AHP (Analytical Hierarchy Process). Pakar akan menentukan penilaian yang berdasarkan skala 1 sampai 9 secara perbandingan berpasangan (pairwise comparision). Menurut Saaty (1983), Marimin dan Maghfiroh (2010) skala 1 sampai 9 definisi pendapat pakar dalam skala perbandingan ada pada Tabel 3.

Tabel 3. Kriteria penilaian dalam AHP

\begin{tabular}{ll}
\hline Nilai & \multicolumn{1}{c}{ Keterangan } \\
\hline 1 & A sama penting dengan B \\
3 & A sedikit lebih penting dari B \\
5 & A jelas lebih penting dari B \\
7 & A sangat jelas lebih penting dari B \\
9 & A mutlak lebih penting dari B \\
$2,4,6,8$ & Apabila ragu-ragu antara dua nilai yang berdekatan \\
\hline
\end{tabular}

Sumber: Saaty (1983), Marimin dan Maghfiroh (2010)

Kriteria yang akan digunakan untuk menentukan indeks potensi pengembangan kawasan wisata pantai, yaitu: penerimaan masyarakat, ketersediaan sarana pariwisata, aktraksi budaya, dukungan industri pariwisata, dan dukungan pemerintah. Pakar yang akan dijadikan expert berasal dari beberapa golongan, yaitu: Dinas Pariwisata Kota Padang, Perguruan Tinggi, tokoh masyarakat, palaku industri pariwisata, LSM, tokoh agama, dan Bappeda Kota Padang. Jumlah pakar sebanyak 25 orang pakar.

Untuk menganalisis menggunakan software Expert Choice 2011. Selain itu, Marimin dan Magfiroh (2010) dan Umar (2016) menyatakan nilai consistency ratio (CR) yang dapat diterima yakni kurang dari 0,1. Gambar 2 disajikan struktur hierarki potensi pengembangan 
wisata pantai di Kota Padang. Hasil penilaian pakar terhadap indeks prioritas pengembangkan objek wisata pantai disajikan pada Tabel 4.

Tabel 4. Indeks penilaian pakar

\begin{tabular}{lll}
\hline Kelas Indeks & Interval & \multicolumn{2}{c}{ Keterangan } \\
\hline Tinggi & $>0,25$ & \multicolumn{2}{c}{ Sangat bagus dikembangkan } \\
Sedang & $0,15-0,25$ & Cukup bagus untuk \\
& $<0,15$ & dikembangkan \\
Kurang & \multicolumn{2}{c}{ Tidak bagus untuk dikembangkan } \\
\hline
\end{tabular}

Sumber : Umar (2017)

Goal/tujuan

Indek Potensi Pengembangan Wista Pantai Di Kota Padang

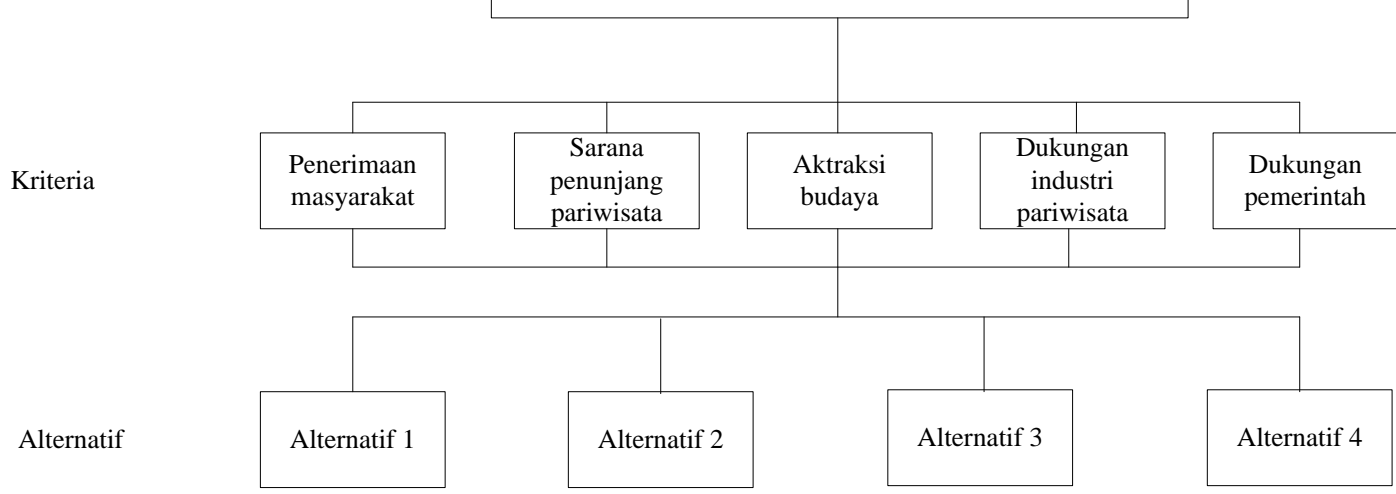

Alternatif 1 = pantai Pasir Jambak

Alternatif $2=$ pantai Muoro Lasak

Alternatif $3=$ pantai Muoaro Padang

Alternatif $4=$ pantai Bungus (Karolin)

Gambar 2. Struktur Hierarki Potensi Pengembanga Wisata Pantai Di Kota Padang

Penentuan zona prioritas pengembangan objek wisata pantai di Kota Padang berdasarkan pada model yang dikembangkan Umar (2017), penentuan prioritas pengembangan objek wisata dapat dilakukan dengan mempertimbangkan kesesuaian lahan untuk objek wisata dan indeks potensi pengembangan objek wisata. Kawasan yang menjadi prioritas untuk dikembangkan sebagai objek wisata yakni zona sangat sesuai (S1) dan memiliki indeks potensi pengembangan wisata hasil penilaian pakar dengan kelas indeks tinggi. Oleh karena itu untuk menentukan prioritas pengembangan kawasan digunakan persamaan 2 .

$$
\operatorname{Pr}=\text { Kow } \mathrm{x} \text { Ppw }
$$

Keterangan :

$\operatorname{Pr}=$ prioritas pengembangan objek wisata

Kow $=$ skor kesesuaian lahan untuk objek wisata

Ppw $=$ skor indeks potensi pengembangan objek wisata 


\section{HASIL DAN PEMBAHASAN}

Kota Padang secara geomorfologi dapat dibedakan atas tiga bentuk lahan, yakni bentuklahan asal proses vulkanik, bentuklahan asal proses fluvial, dan bentuklahan asal proses marin. Bentuklahan asal proses vulkanik terdapat pada bagian timur Kota Padang, bentuklahan asal proses fluvial pada bagian tengah, dan bentuklahan asal proses marine terdapat pada bagian barat. Endarto (2007) menjelaskan bentuklahan asal proses vuknik merupakan bentuklahan yang terbentuk karena proses atau asal bentukan tenaga vulkanik, bentuklahan asal proses fluvian merupakan bentuklahan yang terbentuk karena proses tenaga air, dan bentuklahan asal proses marin merupakan bentuklahan yang terbentuk karena pengaruh aktivitas gelombang dan arus laut.

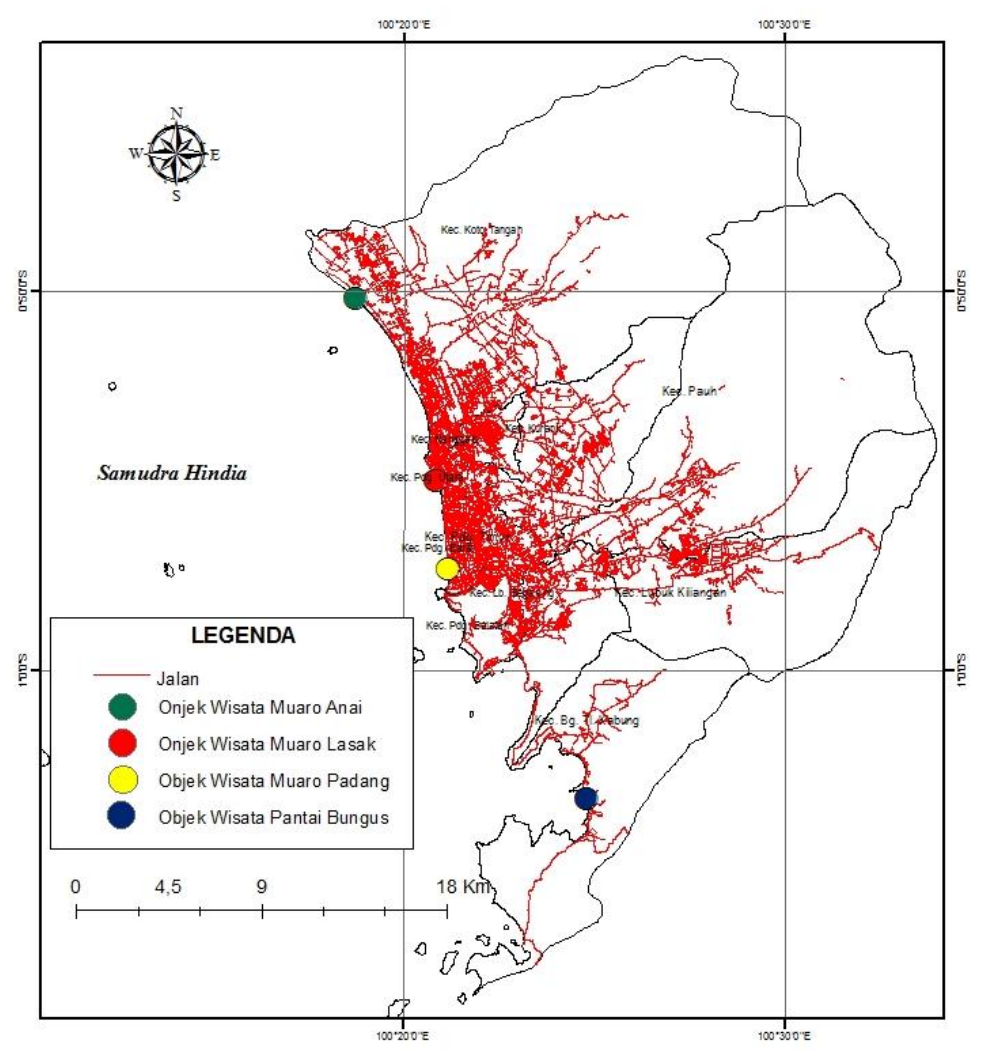

Gambar 3. Distribusi Ojek Wisata Pantai di Kota Padang

Kota Padang memiliki garis pantai sepanjang $23 \mathrm{~km}$ dan berbatasan dengan Samudera Hindia. Sebagai akibat berhadapan dengan sumedera, pantai di Kota Padang memiliki gelombang dan arus yang relatif besar. Selaain itu, di sepanjang pantai di Kota Padang memiliki gugusan pulau-pulau karang yang memiliki daya tarik tersendiri bagi pengunjung. Kota Padang memiliki empat objek wisata pantai yang memiliki daya tarik untuk dikembangkan, yakni: a) objek wisata Pantai Muaro Anai (Pasir Jambak), b) objek wisata Muaro Lasak, c) objek wisata Muaro Padang, dan d) objek wisata Pantai Bungus. Distribusi objek wisata pantai di Kota Padang disajikan pada Gambar 3. 
Tabel 5. Hasil Analisis Evaluasi Kesesuaian Lahan Objek Wisata

\begin{tabular}{lcccc}
\hline \multirow{2}{*}{ Indikator } & \multicolumn{3}{c}{ Objek wisata } \\
\cline { 2 - 5 } & $\begin{array}{c}\text { Objek Wisata } \\
\text { Muaro Anai }\end{array}$ & $\begin{array}{c}\text { Objek Wisata } \\
\text { Muaro Lasak }\end{array}$ & $\begin{array}{c}\text { Objek Wisata } \\
\text { Muaro Padang }\end{array}$ & $\begin{array}{c}\text { Objek Wisata Pantai } \\
\text { Bungus }\end{array}$ \\
\hline Kecerahan perairan & 30 & 15 & 15 & 30 \\
Tipe pantai & 45 & 60 & 60 & 60 \\
Kedalaman pantai & 60 & 30 & 30 & 45 \\
Substrat & 30 & 40 & 40 & 20 \\
Kecepatan arus & 40 & 30 & 30 & 30 \\
Tutupan karang hidup & 15 & 5 & 5 & 10 \\
Rawan bencana & 60 & 45 & 45 & 45 \\
Aksesbilitas & 50 & 50 & 50 & 30 \\
\hline Total Skor & 330 & 275 & 275 & 270 \\
Indeks Kesesuaian & S1 & S2 & S2 \\
\hline
\end{tabular}

Sumber : Analisis 2017

Hasil analisis kesesuaian lahan untuk kawasan objek wisata pantai (Tabel 5) di Kota Padang menunjukkan bahwa objek wisata pantai Bungus (Karolin) termasuk zona sangat sesuai (S1). Selain itu, tiga objek wisata yang lain yakni: objek wisata pantai Muaro Anai (pasir Jambak), objek wisata pantai Muaro Lasak, dan objek wisata Muaro Padang masuk pada ketegori zona sesuai (S2). Menurut Sitorus (2004), Hardjowigeno dan Widiatmaka (2007), dan Baja (2012) menyatakan bahwa penggunaan lahan yang tidak sesuai dengan kesesuailan lahan akan membutuhkan biaya tambahan untuk perbaikan lahan, hal ini berarti semakin semain banyak faktor-faktor pembatas suatu objek wisata maka akan membutuhkan biaya yang mahal untuk perbaikan lingkungan.

Berdasarkan indeks penilaian potensi pengembangan objek wisata di Kota Padang dengan lima kriteria yakni penerimaan masyarakat, ketersediaan sarana pariwisata, aktraksi budaya, dukungan industri pariwisata, dan dukungan pemerintah maka nilai yang tertinggi yakni penerimaan masyarakat (sebesar 40,6\%). Hal ini berarti bahwa kriteria yang paling besar untuk dijadikan dasar pengembangan objek wisata adalah penerimaan masyarakat. Karena banyak perencanaan pengembangan suatu kawasan terutama objek wisata tidak mendapat dukungan dari masyarakat, karena bertentangan dengan nilai-nilai suatu masyarakat. Baja (2012) menjelaskan bahwa dalam perencanaan suatu wilayah perlu melibatkan masyarakat, dengan keterlibatan masyarakat dalam perencanaan suatu wilayah maka dapat mengakomodir seluruh kepentingan masyarakat. Primadani dkk. (2014) menyatakan bahwa keberhasilan perencanaan pengembangan pariwisata sangat ditentukan dengan adanya dukungan masyarakat, sehingga perlu melibatkan dan mengakomodasi semua kepentingan masyarakat.

Unga dkk. (2010) menyatakan bahwa dalam perencanaan pengembang pariwisata mesti mempertimbangkan beberapa indikator, yaitu: dukungan masyarakat, tersedianya sarana prasarana penunjang, aktraksi budaya, dan dukungan pemerintah. Tanpa adanya memperhatikan empat indikator tersebut, maka keberhasilan dalam perencanaan sulit untuk dicapai. Hasil analisis indeks potensi pengembangan pariwisata pantai di Kota Padang dengan menggunakan metode AHP menunjukkan bahwa objek wisata pantai Muaro Lasak dan Muaro Padang memiliki nilai indeks potensi yang sangat baik (tinggi) untuk dikembangkan. Hasil penilaian pakar perhadap indeks potensi pengembangan objek wisata pantai disajikan pada Gambar 4.

Prioritas pengembangan objek wiata pantai di Kota Padang ditentukan dengan menggunakan persamaan 2. Prioritas ditentukan berdasarkan dua faktor, yaitu: kesesuaian lahan objek wisata dan indeks potensi pengembangan objek wisata. Hasil analisis terhadap empat objek wisata pantai di Kota Padang menunjukkan bahwa objek wisata pantai Muaro Lasak menjadi prioritas utama untuk dikembangkan. Prioritas pengembangan objek wisata pantai di Kota Padang disajikan pada Tabel 6. 


\title{
Model Name: Indeks Potensi Pengembangan Objek Wisata
}

\author{
Synthesis: Summary
}

Sunthesis with resped to:

Goal: Indeks Potensi Penqembanqan Objek Wis ata Pantai Di Kota Padan

0 verall Inconsistenor $=, 03$

\begin{abstract}
Obiek wis ata pantai Muaro Anai Ipasir J amb.. Obiek wisata pantai Muaro Lasak Objek wisata pantai Muaro Padanq

Objek wis ata pantai Bunqus |Karolini
\end{abstract}

.092

.361

.348

.199

Gambar 4. Hasil penilaian pakar

Tabel 6. Prioritas Pengembangan Objek Wisata Pantai di Kota Padang

\begin{tabular}{lcccc}
\hline Objek Wisata & Skor Kesesuaian lahan & Indeks Potensi & Skor & Prioritas \\
\hline Muaro Anai & 330 & 0,092 & 30,36 & 4 \\
Muaro Lasak & 275 & 0,361 & 99,28 & 1 \\
Muaro Padang & 275 & 0,348 & 95,70 & 2 \\
Bungus & 270 & 0,199 & 53,73 & 3 \\
\hline
\end{tabular}

Sumber : Analisis (2017)

\section{KESIMPULAN}

Kota Padang memiliki objek wisata pantai yang potesial untuk dikembangkan karena memiliki daya tarik dan keindahan paintai yang jernih. Kunjungan wisata baik domestik maupun mancanegara meningkat sebesar 2,6 \% setiap tahunnya. Berdasarkan kesesuaian lahan objek wisata Muaro Anai sangat sesuai (S1)untuk kawasan objek wisata, namun berdasarkan indeks potensi pengembangan objek wisata memiliki skor terendah. Hasil analisis prioritas pengembangan objek wisata pantai Muaro Lasak menjadi prioritas utama untuk dikembangkan di Kota Padang. Faktor pendorong prioritas pengembangan objek wisata Muoaro Lasak terletak pada indeks potensi pengembangan objek wisata yakni sebesar 0,361. Upaya untuk meningkatkan kelas kesesuaian lahan pada objek wisata Muaro Lasak maka perlu adanya perbaikan lingkungan sebagai limiting factor (faktor pembatas).

Kepada pemerintah Kota Padang disarankan agar mengembangkan objek wisata yang memiliki prioritas utama untuk dikembangkan. Pengembangan objek wisata akan berdampak terhadap penyerapan tenaga kerja sebesar 1,4\% per tahunnya.

\section{DAFTAR PUSTAKA}

Aklibasinda, M., dan Bulut, Y. 2014. Analysis of terrains suitable for tourism and recreation by using geographic information system (GIS). Environmental Monitoring and Assessment, 186(9): 5711-5720.

Badan Pusat Statistik [BPS]. 2016. Indonesia dalam Angka. Badan Pusat Statistik. Jakarta.

Baja, S., 2012. Tata Guna Lahan dalam Pengembangan Wilayah. Penerbit Andi. Yogyakarta.

Endarto, D., 2008. Pengantar Geomorfologi Umum. Penerbit Lembaga Pengembangan Pendidikan (LPP) UNS dan UPT Penerbitan dan Perctakan UNS (UNS Press). Surakarta. 
Hawkes, S., Williams, P., \& Penrose, R., 1998. Tourism industry perspectives on the cariboo-chilcotin CORE process. Environments, 25 (2): 48-51.

Hardjowigeno, S., dan Widiatmaka. 2007. Evaluasi Kesesuaian Lahan dan Perencanaan Tataguna Lahan. Gadjah Mada University Press. Yogyakarta.

Masron, T., Mohamed, B., dan Marzuki, A., 2015. Gis Base Tourism Decision Support System For Langkawi Island, Kedah, Malaysia. Theoretical and Empirical Researches in Urban Management, 10(2): 21-35.

Marimin, dan Maghfiroh, N., 2010 . Aplikasi Teknik Pengambil Keputusan dan Manajemen Rantai Pasok. IPB Press. Bogor

Primadany, S. R., Mardiyono, dan Riyanto. 2014. Analisis Strategi Pengembangan Pariwisata Daerah. Jurnal Administrasi Publik (JAP), 1(4) : 135-143.

Sitorus, S.R.P., 2004. Evaluasi Sumberdaya Lahan. Edisi Ketiga. Penerbit Tarsito. Bandung.

Unga, K. L., Benyamin, I. M., dan Al, R. 2010. Stratege Pengembangan Kawasan Wisata Pulau Banda. Jurnal Administrasi Publik (JAL), 1 (3) : 1-10.

United States Department of Agriculture [USDA], 1971.Guide for Interpreting Engineering Uses of Soils. US. Dept. of Agriculture. Washington DC.

Umar , I., 2016. Mitigasi Bencana Banjir Kawasan Permukiman di Kota Padang. (Disertasi). Sekolah Pascasarjana IPB. Bogor.

Umar, I., Widiatmaka, Pramudya , B., dan Barus, B., 2017. Prioritas Pengembangan Kawasan Permukiman pada Wilayah Rawan Banjir Di Kota Padang Provinsi Sumatera Barat. Majalah Ilmiah Globe , 19 (1): 1-10.

Zhang, J. 2013. The issues facing the sustainable development of rural tourism and the path selection. Asian Agricultural Research , 5 (9): 5-7. 